\title{
Turkish High School Teachers' Conceptions of Creativity in Mathematics
}

\author{
Meral Cansız Aktaş \\ Correspondence: Meral Cansız Aktaş, Department of Elementary Education, Ordu University, Ordu, Tel.: +90 \\ 0452 2265250, Turkey
}

$\begin{array}{lcc}\text { Received: October 9, } 2015 & \text { Accepted: October 20, } 2015 \quad \text { Online Published: October 23, } 2015 \\ \text { doi:10.11114/jets.v4i2.1123 } & \text { URL: http://dx.doi.org/10.11114/jets.v4i2.1123 }\end{array}$

\begin{abstract}
The aim of this research is to explore Turkish high school teachers' conceptions of creativity in mathematics. The research was carried out using qualitative research methods. The sample consisted of seven mathematics teachers, and semi-structured interviews were used as a data collection tool. Analysis of the responses indicated that mathematics teachers' conceptions of creativity were limited to developing a different perspective and finding a solution using this different perspective. Creative mathematics teachers were described as having some professional abilities rather than personality traits by the teachers. Standardized tests, curriculum limitations, and the education system were given as some of the barriers to fostering creativity. The study shows that Turkish high school mathematics teachers' conceptions of creativity were narrow and the factors inhibiting creativity were attributed to characteristics of the education system rather than those of the teachers themselves.
\end{abstract}

Keywords: creativity, creative thinking, mathematics teachers, teachers' conceptions

\section{Introduction}

Researchers, teachers, and politicians consider creativity to be a component in promoting economic production and a motivating factor in education (Hondzel, 2013). It is regarded important nearly in every field. In accordance with this, the European Union announced 2009 as the European Year of Creativity and Innovation to raise awareness of creativity and innovation, skills which play an important role in individual, social, and economic development, and to reinforce the focus on these skills in areas such as education, business, culture and research. The number of policy statements and projects in education which have called for fostering creativity in educational settings and incorporating creativity into the school curriculum has been increasing since the end of the 1990s (Craft, 2003). In addition, the Trends in International Mathematics and Science Study (TIMSS) and the Program in International Student Assessment (PISA) highlight the importance of creative problem solving (Sheffield, 2005). In this context, the importance of creativity and creative thinking has been emphasized with laws, regulations, and curriculum by the Ministry of National Education in Turkey. The development of creative thinking skills and the education of individuals who are fully developed in terms of creativity are among the aims in primary education and secondary education regulations. A purpose of mathematics education is to promote mathematical creativity. However, this concern has had minimal impact on research in Turkey, because few studies exist about creativity in mathematics and they were conducted with pre-service mathematics teachers (Kandemir \& Gür, 2007; Kiymaz, 2009). It is obvious that the teachers certainly play a key role in the development of creativity due to the fact that they are the main mediators between the curriculum and classroom practices. On the other hand, little is known about how mathematics teachers conceptualize creativity. This study explores conceptions of creativity held by high school mathematics teachers in Turkey.

\subsection{Creativity}

Although researchers emphasized the importance of creativity, the literature does not show that a consensus on the definition of creativity has been reached (Meissner, 2005) and that creativity has been described as an unexplored concept (Ervynck, 1991). Mann (2006) examined the research carried out in an attempt to define creativity and presented more than a hundred definitions of creativity. Sriraman (2005) remarked that due to the complex nature of creativity, most of the extant definitions were vague and complicated. For example, creativity has been defined as an individual's production of something new and unpredictable (Pehkonen, 1997) and an ability to offer a solution to a problem or to make something useful or novel from something ordinary (Hwang, Chen, Dung, and Yang (2007). Treffinger, Young, Selby, and Shepardson (2002) and Shriki (2010) argued that the extant definitions of creativity meant production of something novel, that is, the definitions were related to the production of an outcome. Furthermore, many 
studies (Isaksen, Dorval, \& Treffinger, 2000; Lev-Zamir \& Leikin, 2011) adopt fluency, flexibility, originality, and elaboration as the main components of creativity. Fluency relates to the different responses, the algorithms, which are procedures for solving problems, or the number of new questions formulated. Flexibility is associated with the number of different categories of responses, methods, or questions. On the other hand, originality is characterized by solutions, methods, or questions requiring unique ways of thinking. Elaboration is the ability to generate an idea and develop it further.

\subsection{Creativity in Mathematics}

Florida and Goodnight (2005) argue that creativity is valuable for individuals and society, is universal, and is essential for growth in any field. Creativity in mathematics can be characterized in many ways: the application of non-algorithmic ways (Ervynck, 1991); the offering of perceptive and unusual solutions to the problem, the generation of new questions, and/or the solution of an old problem using a new perspective which requires imagination (Sriraman, 2005); domain-specific thinking processes used by mathematicians to solve non-routine problems (Chamberlin and Moon, 2005); students' ability to solve routine, non-routine problems, and even ill-structured problems (Chiu, 2009); and divergent and flexible thinking which enables the pursuit of different ways and perspectives while solving a problem (Haylock, 1997). As it is seen, mathematical creativity does not have a definition which is accepted by everyone. Mann (2006) stated that the lack of an accepted definition impedes relevant research efforts. In fact, Haylock (1987) reviewed the relevant literature between 1966 and 1985 and noted that the subject of mathematical creativity was neglected in mathematics education research. When reviewing the studies from 1999 to 2009, Leikin $(2009,2011)$ demonstrated that the situation did not change and very few publications were devoted to creativity when compared to the studies conducted on mathematical thinking, learning, and instruction. One of the reasons for this might be that mathematics is considered to be one of the courses which offer fewer opportunities for creativity (Pehkonen, 1997). In this context, Beghetto (2007) argued that creative thinking was neglected by teachers in courses such as mathematics, where acquiring algorithms are considered to be superior and creativity was regarded as diversion.

\subsection{Creative Teaching in Mathematics}

Best and Thomas (2007) suggest that teachers' professional and personal traits are important for creative teaching in mathematics. The professional domain includes the teacher's role in developing creativity during instruction and the personal domain includes a variety of traits such as self-confidence, openness to experience, flexibility of thoughts, and imagination. Many qualities related to the professional domain, such as avoiding rote learning, benefiting from a variety of teaching methods and technology (Horng, Hong, ChanLin, Chang \& Chu, 2005), and including open-ended and non-routine problems which give students freedom to use their imagination and find new methods or solutions (Shriki, 2008), foster creativity in learning environments. Among these problems, multiple solution tasks are mainly associated with mathematical creativity (Ervynck 1991; Leikin, 2009). Sheffield (2008) stressed although it is important to calculate and solve routine problems in mathematics, to be creative, students should recognize and define the problems, solve these problems in different ways, reason, and justify the results. According to Sheffield (2008), students were not born with these skills and they cannot develop them on their own resulting in close attention to the development of these skills.

\subsection{Teachers' Conceptions of Creativity}

Shriki (2005, in Shriki, 2010) argues that though many mathematics teachers value the growth of creativity, most of them do not have the essential skills to reinforce students' creativity, such as lack of experience. Educators share the common responsibility that students be taught and encouraged to be creative. Thus, because creativity can either be promoted or hindered in the classroom, it is important to understand the factors which affect teachers' conceptions of students' creativity (Rubenstein, McCoach \& Siegle, 2013). There is no doubt that if teachers show awareness of this topic, individuals can be equipped with creative thinking skills in mathematics. Thus, it becomes important to examine how teachers think about creativity.

However, the research literature devoted to analysis of teachers' conceptions of creativity shows that this issue has been underdeveloped in mathematics education research (Leikin, 2009, 2011). Lev-Zamir and Leikin (2011) explored teachers' conceptions of creativity in teaching mathematics by devising a model. They adopt four main components of creativity: fluency, flexibility, originality, and elaboration. As fluency is considered to be the primary characteristic of teachers' knowledge and proficiency, teachers' statements related to creativity in teaching mathematics were classified as fitting into one of the three of the four categories- flexibility, originality, and elaboration. They argued that in teaching mathematics teachers' conceptions of creativity consist of two main types. The acts by teacher that make students creative were called as teacher-directed conceptions and connecting creativity with opportunities provided while teaching mathematics were called as student-directed conceptions. In this model, teacher-directed conceptions of creativity were of mathematical or pedagogical kind. Teachers' mathematical flexibility was associated with 
transformations of mathematical activities and different solutions to problems or the use of various kinds of teaching. The category of mathematical originality includes the generation of original mathematical activities which are not included in the textbook. Teachers' pedagogical flexibility is related to transformation of the instructional setting and adaptation of the activities to the students' cognitive level, namely, the generation of new pedagogical ideas. Pedagogical originality includes curriculum and in-class implementations and teachers' actions and statements that are unconventional or unusual. On the other hand, student-directed conceptions of creativity include the categories of flexibility, which consists of various student-generated solutions to problems that are different from those generated previously; originality, which includes generating new and original ideas and offering rare, perceptive solutions to a problem; and elaboration, which includes student actions such as generalizing mathematical ideas and raising the level of mathematical discussions.

\subsection{Rationale and Problem Statement}

Teachers' conceptions of creativity can influence the ways they attempt to encourage creativity in the classroom (Bryant, 2014). However, there is a gap in the literature in understanding which conceptions teachers have about the promotion of creativity. Teachers are usually unaware of the primary qualities of creative students, most teachers misunderstand creative students or they have negative perceptions of them, and creativity is usually discouraged in the schools (Aljughaiman \& Mowrer-Reynolds, 2005; Hondzel, 2013, Sriraman, 2005). Although there are some studies about teachers' conceptions of creativity around the world (Lev-Zamir \& Leikin, 2011, 2013; Leikin, Subotnik, Pitta-Pantazi, Singer \& Peltzer, 2013), there are not enough studies which reveal mathematics teachers' conceptions of creativity in Turkey. Therefore research are needed to gain insights into the Turkish context and to understand what Turkish teachers consider being creative in mathematics. I think that identifying Turkish mathematics teachers' conceptions of creativity is important for the following reasons: First, teachers' conceptions of creativity reflect cultural values (Hong \& Kang, 2010) and differences in educational systems in different countries are reflected in teachers' conceptions (Leikin, Subotnik, Pitta-Pantazi, Singer \& Peltzer, 2013). Because a similar study has not been carried out with high school mathematics teachers in Turkey, the findings which will be obtained from the study will contribute to reveal teachers' conceptions of mathematical creativity in Turkish culture. Moreover, I believe that this research study will make contributions to similar studies which will be carried out on mathematical creativity, as this is a field of research which has been ignored by research studies in Turkey. The determination of teachers' conceptions can be the first step in defining ways to foster creativity in schools (Beghetto \& Plucker, 2006). It is also a requirement for any policy that will be developed about creativity in education (Cachia \& Ferrari, 2010). Furthermore, whether teachers have misconceptions or prejudices about creativity will be determined and introducing what is needed to eliminate these weaknesses will provide a basis for including better implementations for promoting creativity in classes (Newton \& Newton, 2009). Due to the reasons stated above, I believe that this research will make a contribution to the literature. In this context, the aim of this research is to explore Turkish high school teachers' conceptions of creativity in mathematics. This study sought answers to the following questions:

1. What are mathematics teachers' definitions of creative thinking?

2. What do mathematics teachers think are characteristics of creative mathematics teachers and students?

3. What kinds of activities do mathematics teachers use in the classroom in order to foster creativity?

4. What do mathematics teachers believe are the barriers to creativity?

\section{Method}

\subsection{Research Model and Sample}

The research was carried out using qualitative research methods. The focus of this study is creativity in mathematics. The sample consisted of seven mathematics teachers with different demographic characteristics. The participants in the study were chosen using criterion sampling, a purposeful sampling technique. The criterion sampling method allows the researcher to compose a criterion or a criteria list which is prepared before the study. In this study, teaching experience, graduation, and post-graduate study were determined as criteria. The demographic qualities of the teachers were coded as $\mathrm{T} 1-\mathrm{T} 7$ and are presented in Table 1.

Table 1. Demographic qualities of the participants.

\begin{tabular}{llll}
\hline Teachers & Teaching experience & Graduation & Post graduate studies \\
\hline T1 & $15-19$ years & Faculty of Letters and Science & No \\
T2 & $10-14$ years & Education Faculty & No \\
T3 & $20-25$ years & Education Faculty & No \\
T4 & $20-25$ years & Faculty of Letters and Science & No \\
T5 & $15-19$ years & Faculty of Letters and Science & No \\
T6 & $10-14$ years & Education Faculty & Yes \\
T7 & $10-14$ years & Education Faculty & No \\
\hline
\end{tabular}




\subsection{Data Collection Instrument}

Semi-structured interviews were used as a data collection tool in the research. The interview questions which were used to determine teachers' conceptions were prepared based on previous studies on creativity (Aljughaiman \& Mowrer-Reynolds, 2005) and creativity in mathematics (Lev-Zamir and Leikin, 2011, 2013; Leikin, Subotnik, Pitta-Pantazi, Singer \& Peltzer, 2013). A pilot study using draft questions was then carried out with two teachers who did not participate in the study. After this process, interview questions were reviewed and necessary changes were made. Expert opinions were obtained from two faculty members who examined the interview questions and, based on their suggestions and views, the questions were finalized. During the interviews, the teachers were asked their opinions on the following topics: how they defined creative thinking, the qualities of creative mathematics teachers and students, what kind of activities they used in class to foster creativity, and the factors which hamper creativity. The interviews were carried out in the school where the teachers worked while they were not in class. The interviews lasted nearly 30 minutes and were taped. The teachers verified transcriptions of the recordings of their interviews.

\subsection{Data Analysis}

The data were coded using content analysis with NVivo 9 software. Codes which were similar to each other were clustered within the framework of the themes generated and they were presented descriptively by using direct quotations. Teachers' statements about the characteristics of a creative teacher were examined using Best and Thomas's (2007) categories of professional abilities and personality traits and the professional abilities which were defined were examined in terms of their accountability with teacher-directed conceptions determined by Lev-Zamir and Leikin (2011, 2013). For the reliability of the coding, another researcher was asked to code the data again and inter-rater reliability was calculated at 92\% using Miles and Huberman's (1994) formula (reliability = number of agreements/total number of agreements and disagreements).

\section{Results}

\subsection{Mathematics' Teachers' Definitions of Creative Thinking}

A model generated using teachers' definitions of creative thinking is shown in Figure 1.

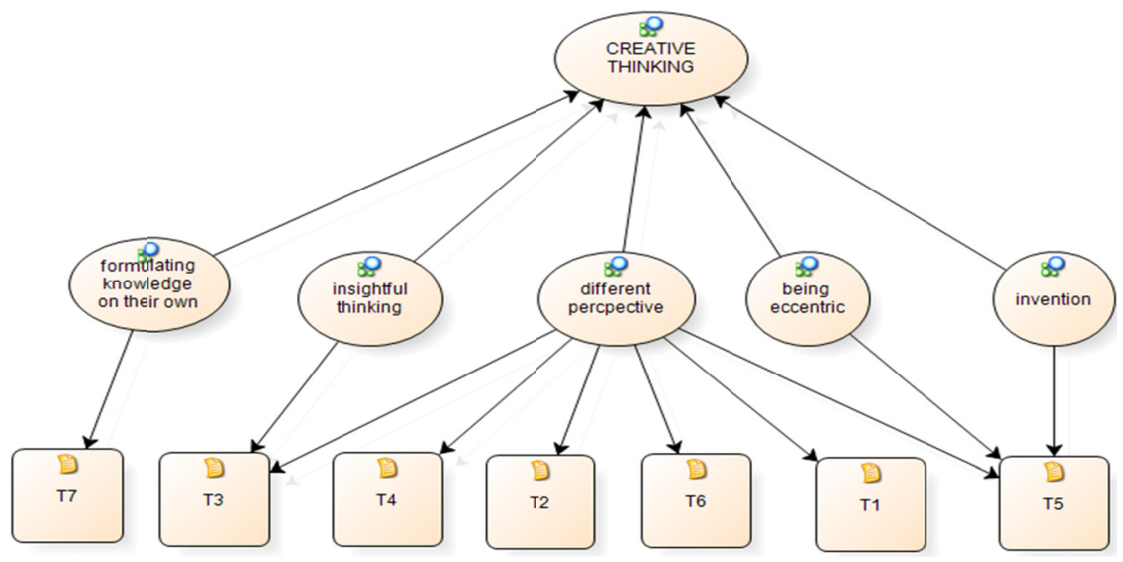

Figure 1. A model of teachers' definitions of creative thinking.

Figure 1 shows that the teachers defined creative thinking with expressions coded as formulating knowledge on their own (T7), insightful thinking (T3), developing a different perspective (T1, T2, T3, T4, T5, and T6), being eccentric (T5), and invention (T5). What draws attention here is that except T7, all teachers gave definitions which were coded as developing a different perspective, e.g., T1, "Developing a different perspective on any concept"; T2, "Drawing conclusions about a subject by looking at it from a different perspective from which many people could not view it"; and T6,

Generating various solutions to a problem different from those existing with the help of learned knowledge, implementing them, and finding a solution... It includes all the skills of realizing that it is not an obligation to use existing knowledge to produce new knowledge and beginning to solve a problem believing that core skills will be sufficient for a solution, actualizing interim work or operations, and determining the result using the solution strategies.

In addition to this, T3 defined creative thinking with the following statement: "Insightful thinking and pursuing your thought to the very end, obtaining a result." T7 defined creative thinking with the expression coded as formulating knowledge on one's own: "The skill of formulating and constructing knowledge on your own." T5 stated, "Inventing something which has not existed before, thinking differently from everyone, being eccentric," which was coded as 
being eccentric and invention.

\subsection{Characteristics of a Creative Mathematics Teacher}

The statements of the teachers about the characteristics of a creative mathematics teacher were categorized into two groups, personality traits and professional abilities, and presented in Table 2.

Table 2. Characteristics of a creative mathematics teacher.

\begin{tabular}{|c|c|c|}
\hline Teachers & Professional Abilities & Personality Traits \\
\hline T1 & $\begin{array}{l}\text { Tries to make learning fun } \\
\text { Proves important properties }\end{array}$ & \\
\hline $\mathrm{T} 2$ & & $\begin{array}{l}\text { Has an interest in technological events } \\
\text { Knowledgeable } \\
\text { Hardworking } \\
\text { Undeterred }\end{array}$ \\
\hline T3 & Guide & \\
\hline $\mathrm{T} 4$ & $\begin{array}{l}\text { Presents examples to show how the concept is used } \\
\text { Concretizes }\end{array}$ & \\
\hline T5 & $\begin{array}{l}\text { Solves a complicated problem } \\
\text { Applies mathematics to everyday examples } \\
\text { Generates a method which has not been discovered before }\end{array}$ & \\
\hline T6 & $\begin{array}{l}\text { Listens to the students } \\
\text { Evokes the importance of thinking } \\
\text { Solves problems which require creative thinking } \\
\text { Keeps abreast of latest developments about the course } \\
\text { Follows the changes in the curriculum } \\
\text { Aims at developing high-order thinking skills }\end{array}$ & \\
\hline $\mathrm{T} 7$ & $\begin{array}{l}\text { Guide } \\
\text { Creates feeling of curiosity } \\
\text { Makes the topic interesting } \\
\text { Gives importance to conceptual knowledge rather than } \\
\text { functional knowledge }\end{array}$ & \\
\hline
\end{tabular}

Table 2 shows that T2 described creative mathematics teachers only using personality traits while the other teachers described them using professional abilities. Another point which draws attention is that the teachers usually mentioned different aspects of the characteristics of a creative mathematics teacher. Only two teachers (T3, T7) stressed the same quality (a creative mathematics teacher being a guide). On this topic T1 stated,

Mathematics must be taught only as mathematics, not as a preparation to any exam.... There must be fun while teaching it and the properties which are very important and will have an impact on a student must be proved.... For example, the Pythagorean Theorem...Mathematics is theorems and proofs.

T7 said the following:

[A teacher] who does not provide knowledge, can only guide you. [A teacher] must certainly raise a feeling of curiosity within the students. [A teacher] must make the topic attractive and interesting. [A teacher] must not be obsessed with the order of operations. [A teacher] must pay attention to the concept and the theme of the subject....

\subsection{Characteristics of Creative Students}

A model generated using teachers' statements about creative students in mathematics is presented in Figure 2.

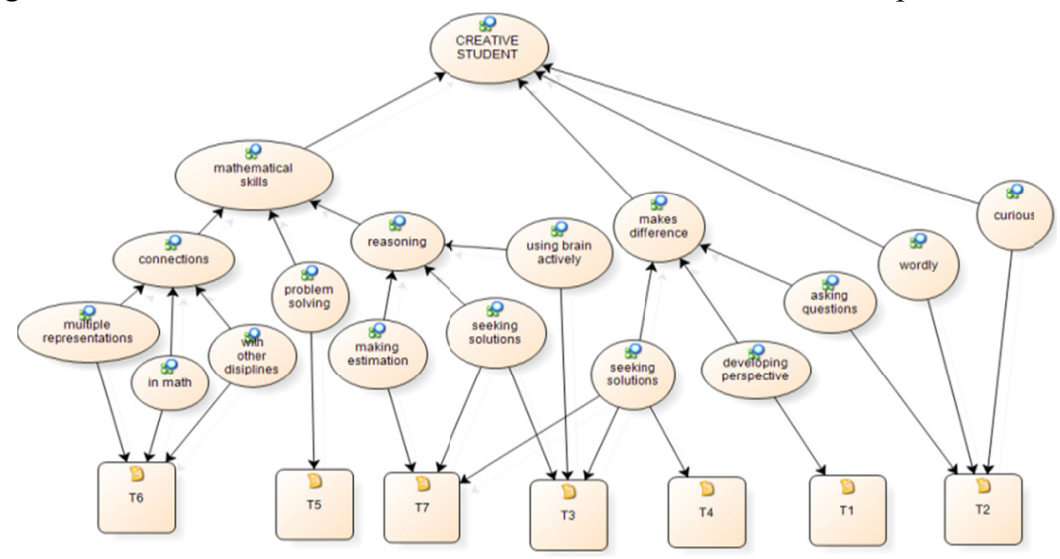

Figure 2. Creative students in mathematics. 
The responses shown in Figure 2 indicate that teachers believed that a creative student should have mathematical abilities. For example, T6 noted that a creative student in mathematics must have the ability to make connections between mathematical concepts:

A creative student is a student who when solving problems produces multiple solutions by making use of knowledge from different learning fields rather than the field which the problem belongs to. Students who can use mathematics in geometry problems and geometry in mathematics problems are examples of this. Students who utilize tables and graphics during problem solving can be included in this group.

Similarly, while talking about a creative student in mathematics, T7 mentioned characteristics which can be associated with reasoning: "A creative student is someone who notices the way to the solution from beginning. A creative student is someone who questions why and reasons. A creative student is a student who tries to produce multiple ways of solving a problem." T5 connected the creative student in mathematics to the student who has an ability to solve a problem: "A student who can solve a problem which he has not confronted before." On the other hand, students who make a difference with such qualities as seeking solutions (T3, T4, and T7), developing a perspective (T1), and asking questions (T2) were qualified as creative students. For example, T3 stated, "Creative students are students who question the causes and effects of solutions, seek other ways to solve, always seek new solutions, and consistently use their brains actively in forming new formations." T4 stated, "A student who makes solutions to problems in a different way than anybody else," and T2 stated, "A student who is curious and worldly and who asks different questions about mathematics."

\subsection{Applying Creativity-fostering Activities in the Classrooms}

A model obtained using the coded statements of mathematics teachers about activities which require creative thinking skills in the lessons is presented in Figure 3.

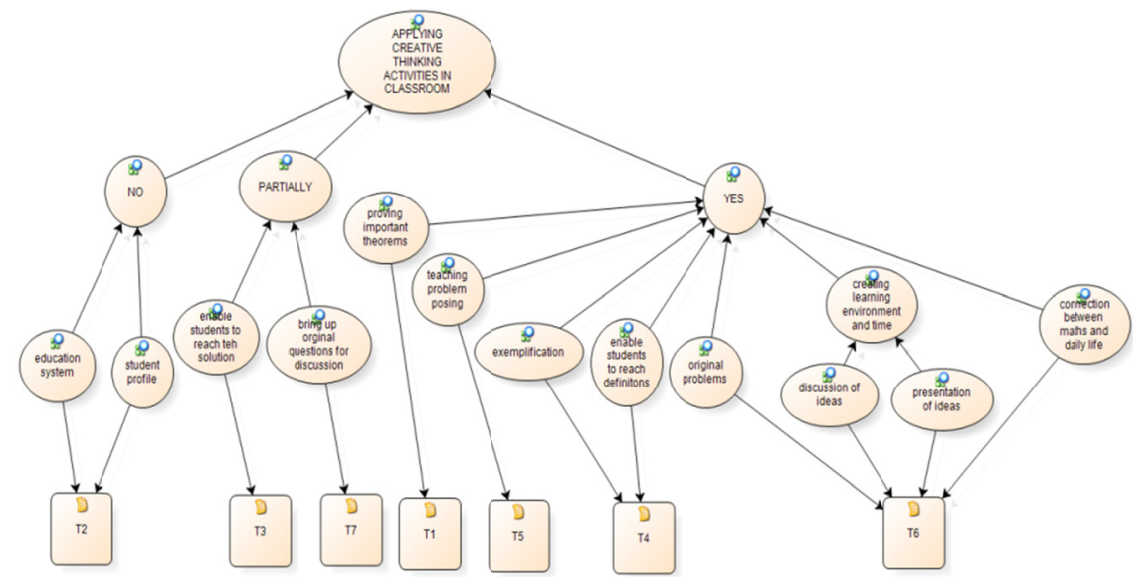

Figure 3. Creative thinking activities in the classroom.

Figure 3 reveals that T2 did not include tasks which required creative thinking skills in lessons, T3 and T7 partially included such tasks, and T1, T4, T5, and T6 included them. T2 did not employ practices which required creative thinking skills and stated: "I teach the course by making students memorize basic concepts because of the education system and student profile. Since creative thinking does not exist in the system, how can I use it?" Note that T2 does not include activities which enable creative thinking skills because the education system and student profile do not allow for their use. Instead of such activities, he teaches by making students memorize some basic concepts. T7, one of the teachers who stated that he partially employed creative thinking skills, stated,

I scarcely employ creative thinking skills in my course due to the quality of the students in the school where I work. However, I certainly bring up the question, "Is a polygon a circle when the number of the sides is increased?" for discussion. I certainly bring up such concepts as empty set, line, and plane for discussion and I try to refute every single answer. For example, is the expression "people yet to be born" a set? Can a similar expression be written?

T6, one of the teachers who stated that he employed creative thinking in his lesson, explained the way he taught with this statement:

I try to use different sources so that my students can see original problems which will trigger them to think. Instead of spending time on having students acquire basic learning outcomes and I attempt to present different problem situations, help them to think, and see that what they learn serves a purpose. I also create a learning environment and time for them to present and discuss their ideas. 


\subsection{Barriers to Fostering Creativity}

A matrix formulated with the coded statements of mathematics teachers about the barriers to fostering creativity is presented in Figure 4.

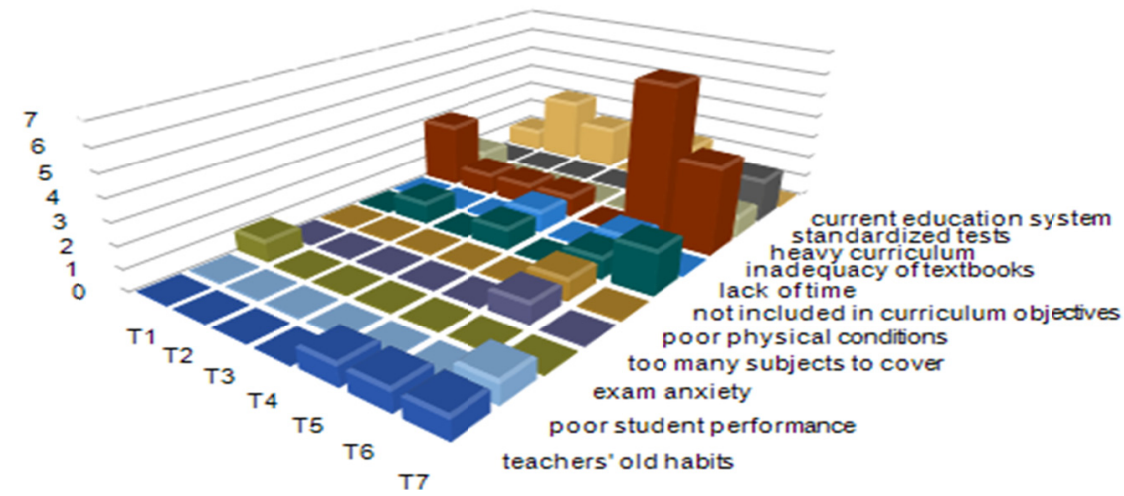

Figure 4. Barriers to fostering creativity

Figure 4 reveals that all the teachers except for T4 regarded textbooks as barriers to fostering creativity skills, but T1, T6, and T7 overemphasized this subject. Moreover, the current education system (T2, T3, and T4), crowded classes (T6), and standardized tests (T7) were regarded as barriers to fostering creativity. The themes presented in Figure 5 were obtained by clustering the codes demonstrating the barriers to fostering creativity.

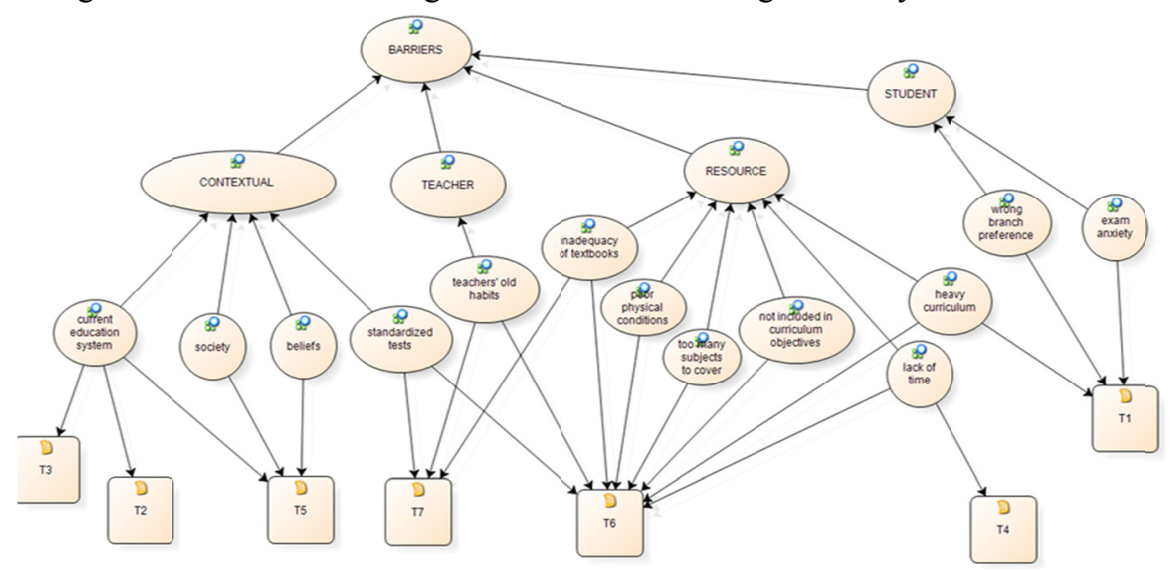

Figure 5. The sources of the barriers.

As shown in Figure 5, the barriers to fostering creativity were classified into these groups by the teachers: student, teacher, resources, and contextual obstacles. What stands out here is that contextual obstacles were mentioned by many teachers (T2, T3, T5, T6, and T7). Specifically, the current education system (T2, T3, and T5) and standardized tests (T6 and T7) were viewed as posing obstacles. When the barriers fitting into the theme of resources were examined, the teachers mentioned such points as inadequacy of textbooks (T6 and T7), lack of time (T4 and T6), and too many subjects to cover (T1 and T6). On the other hand, the views stating teachers' old habits were examined under the theme of teacher-based barriers and exam anxiety and wrong major choices were explored under the theme of student-based barriers. The following extracts are examples of teachers' opinions:

Exam anxiety; too many subjects, whether necessary or not; students who were pushed to the classes by their parents... For example, a student who won't be successful at applied sciences studying in an applied sciences department... (T1)

Society (must show great respect to people with creative thinking), beliefs (we have a saying "creation belongs to God"), education system (education system is based on rote learning and it lacks the asking of questions) (T5)

Lack of time, heavy and tight curriculum, inadequate textbooks, lack of gains and skills in curriculum, poor physical conditions, overcrowded classrooms, incompatible exam questions, teachers' habits... (T6)

\section{Discussion}

Treffinger, Young, Selby, and Shepardson (2002) argue that creativity is an individual activity which is primarily concerned with the production of an outcome that is novel. They base this on the fact that more than 100 definitions of creativity exist in the literature. Teachers' definitions emphasize developing a different perspective and finding a solution based on this different perspective; Turkish mathematics teachers' definitions show some similarities with the 
definitions in the literature. However, many researchers (Alughaiman \& Mowrer-Reynolds, 2005; Isaksen, Dorval, \& Treffinger, 2000; Runco, 2007) state that creativity consists of divergent thinking, fluent and flexible thought, and the ability to elaborate on an idea. This study reveals that the expressions that teachers used in their definitions did not include any similar definitions of creativity. The teachers did not mention generating various solutions for a problem or coming to a solution via different algorithmic patterns, but they stressed thinking differently from everyone and reaching a conclusion. This view was mentioned in many studies in the form of the ability to produce unexpected, original, and useful work (Sternberg \& Lubart, 2000) and to produce a novel and useful outcome (Plucker \&Beghatto, 2004; Chamberlin \& Moon, 2005, p. 38); however, these are not enough for creativity. In the studies which explored teachers' perceptions and beliefs of creativity, teachers defined creativity as an ability or a process which results in products that are unexpected and novel (Diakidoy \& Phtiaka, 2002) or an ability to produce original ideas that can be developed in the classroom (Aljughaiman \& Reynolds, 2005). Teachers' perceptions of creativity in these studies concur with the idea of developing a different perspective which was articulated by teachers in this current study.

It is very clear that a teacher has a key role in teaching creative thinking skills, which are basic skills in the mathematics curriculum which the students are expected to acquire. All the participants in this study except T2 qualified teachers with some set of professional abilities as creative mathematics teachers. However, Renzulli, Gentry, and Reis (2007) show that though it is possible for teachers to use their influence to foster creativity, they can resist it. Karakale (2000) suggests that in order to promote creativity, teachers should encourage students to ask questions, start the lesson or the unit with a question, have students realize that questions do not have one right answer, and emphasize different perspectives and alternatives. On the other hand, according to Özden (2005), a creative teacher is a teacher who respects and responds to unusual questions, values learners' ideas while listening to them and makes them feel respected, encourages learners to learn independently, and helps students learn to cope with failure and frustration and accept them as part of the process. Of the teachers in the current study, only one teacher (T6) made similar statements. T6 listens to his students, makes an effort to make them feel that thinking is important even if they think wrongly, and adjusts the planned course of the lesson to students' needs and responses. T6's responses concur with the conceptions explained in Lev-Zamir and Leikin's $(2011,2013)$ category of pedagogical flexibility, one of the teacher-directed conceptions. Morever, some participants considered a teacher who tries to make learning fun (T1), fosters curiosity (T7), and makes the lesson interesting (T7) to be creative. These characteristics concur with the conceptions explained in the category of pedagogical originality. However, the participants did not use expressions which could be associated with mathematical flexibility, such as teachers solving problems in different ways and using different models in instruction, or with mathematical originality, such as generating original mathematical tasks which are not included in the textbook.

Meissner (2008) states that mathematical knowledge is not enough to prompt and foster creativity and adds that mathematical knowledge must already have been acquired by understanding the qualities of the concepts and relations between the concepts. In this study, according to T6, a creative student is a student who can use multiple representations in mathematics. Morever, students with mathematical abilities such as reasoning (T3 and T7) and problem solving (T5) and students who ask questions (T2) and make a difference with their points of view (T1) were qualified as creative students by the teachers. However, some teachers (T3, T4, and T7) defined students who make a difference by seeking solutions as creative in mathematics. The teachers' expressions which included students' generating various solutions to a problem are similar to the student-directed conceptions presented previously by Lev-Zamir and Leikin (2010, 2013). Describing students who generate various solutions to a problem or approach a problem from different angles as creative reveals that teachers actually have suggested views which can be the indicators of divergent thinking in literature. However, they did not mention any practices they employed in the classroom to help students acquire these qualities. This may be due to the teachers' belief that creative students can do these things on their own. Another possibility is that teachers may prefer to employ practices intended to find one right answer rather than multiple solutions in order to cover the content of the course in the allotted time. Aljughaiman and Mowrer-Reynolds (2005), who obtained similar findings, determined that this situation might have resulted from teachers considering helping students gain creative thinking skills to be an issue separate from the curriculum.

Although Sriraman (2005) agrees with many teachers' opinions that students' creativity must be fostered, he states that creativity is not usually encouraged in schools. In interviews conducted with teachers about employing creativity-fostering tasks in the classroom, T2 stated that he did not employ such teaching practices in his lessons due to the education system and the student profile. T7 stated that because of the low level of the students, he could not include such practices in his lessons. This is similar to findings in a study conducted by Cheng (2010) regarding creative thinking in which teachers considered low student performance to be one of the things which caused tension most frequently. The teachers (T1, T4, T5, and T6) who remarked that they employed practices which promoted creative thinking in their lessons mentioned the following: proving important theorems, teaching how to ask questions, reaching a definition, including original problem situations, revealing the relationship between everyday life and mathematics, 
and creating an environment and time for students to discuss and present their opinions. Mann (2006) argues that students should be provided with opportunities to design and answer their own problems in order to foster creativity. In our study, since only one teacher (T5) mentioned this point, teachers usually did not employ such practices in their lessons. Sriraman (2004) remarks that students should be given the opportunity to solve non-routine problems that require in-depth thinking, motivation, and perseverance in order to promote mathematical creativity in the class. In this research, only T6 stated that he included original problem situations, which reveals that teachers usually employed practices other than those designed to foster creative thinking skills that were stated in the literature (Sriraman, 2004).

In this study, barriers which teachers considered as barriers to creativity show similarities to those shown in previous studies. For example, standardized tests that determine students' future were demonstrated as barriers to fostering creativity by teachers. Studies (Geist \& Horn, 2009; Longo, 2010) have shown that teachers could not employ practices which foster creativity and were pressured by the priority to help students succeed in exams. Kiymaz (2009) stated that the university preparation process had an important effect on pre-service teachers' employment of creative thinking skills during problem-solving situations and, because of time pressure during exams, problem-solving behaviors of many students were product oriented in order to reach a solution correctly and quickly. Heavy and tight curriculum, the low level of students, education systems, etc., were among the barriers teachers mentioned, but the teachers did not mention themselves as reasons for hindering creativity. This shows that teachers did not hold themselves accountable for hindering creativity (Leikin, Subotnik, Pitta-Pantazi, Singer \& Peltzer, 2013).

In this study, teachers' conceptions of creativity were explored via interviews. I suggest that classroom observations should be included in future research in order to examine any difference between what teachers say and do in the classroom. Since the study was conducted using qualitative research methods, the findings obtained are not generalizable. Therefore, further research conducted with a larger population using qualitative or mixed research methods can provide an opportunity to examine the topic from a different and broader perspective.

Note: This research is the extended format of the paper which was presented at EJER Congress 2014 in İstanbul, Turkey.

\section{References}

Aljughaiman, A., \& Mowrer-Reynolds, E. (2005). Teachers' conceptions of creativity and creative students. Journal of Creative Behavior, 39, 17-34. http://dx.doi.org/ 10.1002/j.2162-6057.2005.tb01247.x

Beghetto, R. A. (2007). Does creativity have a place in classroom discussions? Prospective teachers' response preferences. Thinking Skills and Creativity, 2, 1-9. http://dx.doi.org/ 10.1016/j.tsc.2006.09.002

Beghetto, R. A., \& Plucker, J. A. (2006). The relationship among schooling, learning and creativity. In J. C. Kaufman \& J. Baer (Eds.), Creativity and reason in cognitive development (pp. 316-332). New York: Cambridge University Press. http://dx.doi.org/10.1017/CBO9780511606915.019

Best, B., \& Thomas, W. (2007). The Creative Teaching and Learning Toolkit. Continuum International Publishing Group: New York.

Bryant, S. L. (2014). Queensland teachers' conceptions of creativity: A phenomenographic investigation. (Doctoral dissertation). http://eprints.qut.edu.au/70237/1/Sandra_Bryant_Thesis.pdf.

Cachia, R., \& Ferrari, A. (2010). Creativity in Schools: A Survey of Teachers in Europe. Seville: European Commission - Joint Research Centre -Institute for Prospective Technological Studies. http://ftp.jrc.es/EURdoc/JRC59232.pdf.

Chamberlin, S. A., \& Moon, S. M. (2005). Model-Eliciting activities as a tool to develop and identify creatively gifted mathematicians. The Journal of Secondary Gifted Education, 17, 37-47. http://dx.doi.org/ 10.4219/jsge-2005-393

Cheng, V. M. Y. (2010). Tensions and dilemmas of teachers creativity reform in a Chinese context. Thinking Skills and Creativity, 5, 120-137. http://dx.doi.org/10.1016/j.tsc.2010.09.005

Chiu, M. S. (2009). Approaches to the teaching of creative and non-creative mathematical problems. International Journal of Science and Mathematics Education, 7(1), 55-79. http://dx.doi.org/ 10.1007/s10763-007-9112-9

Craft, A. (2003). The limits to creativity in education: Dilemmas for the educators. British Journal of Educational Studies, 51. http://dx.doi.org/10.1111/1467-8527.t01-1-002299

Diakidoy, I. N., \& Phtiaka, H. (2002). Teachers' beliefs about creativity. In S. P. Shohov (Ed.), Advances in psychology research, 15. (pp. 173-188). Hauppauge, NY: Nova Science Publishers, Inc.

Ervynck, G. (1991). Mathematical Creativity. In Advanced Mathematical Thinking. D. Tall (Ed.), (p. 42-53). Dordrecht: Kluwer Academic Publishers.

Florida, R., \& Goodnight, J. (2005). Managing for creativity. Harvard Business Review, 83(7), 124-131. 
Geist, E., \& Horn, J. (2009). Encouraging creativity in the face of administrative convenience: How our schools discourage divergent thinking. Education, 130, 141-150.

Haylock, D. (1997). Recognizing mathematical creativity in school children. Zentralblatt für Didaktik der Mathematik, $29,68-74$.

Haylock, D. W. (1987). A framework for assessing mathematical creativity in school children. Educational Studies in Mathematics, 18(1), 59-74. http://dx.doi.org/10.1007/s11858-997-0002-y

Hondzel, C. D. (2013). Fostering creativity: Ontario teachers' perceptions, strategies, and experiences (Doctoral dissertation).

Hong, M., \& Kang, N. H. (2010). South Korean and the US secondary school science teachers' conceptions of creativity and teaching for creativity. International Journal of Science and Mathematics Education, 8(5), 821-843. http://dx.doi.org/10.1007/s10763-009-9188-5

Horng, J. S., Hong, J. C., ChanLin, L. J., Chang, S. H., \& Chu, H. C. (2005). Creative teachers and creative teaching strategies. International Journal of Consumer Studies, 29(4), 352-358. http://dx.doi.org/ 10.1111/j.1470-6431.2005.00445.x

Hwang, W., Chen, N., Dung, J., \& Yang, Y. (2007). Multiple representation skills and creativity effects on mathematical problem solving using a multimedia whiteboard" system. Educational Technology \& Society, 10, 191-212.

Isaksen, S., Dorval, K., \& Treffinger, D. (2000). Creative approaches to problem solving. Dubuque, Iowa: Kendall/Hunt Publishing Company.

Kandemir, M. A., \& Gür, H. (2007). Creativity training in problem solving: A model of creativity in mathematics teacher education. New Horizons in Education, 55(3), 107-122.

Karakale, S. (2000). Yaratıcılık ve yaratıcılığın geliştirilmesinde eğitimcilerin rolü. Yasadıkça Eğitim, 67, 11-15.

Kıymaz, Y. (2009). Ortaöğretim matematik öğretmen adaylarının problem çözme durumlarındaki matematiksel yaratıcllkları üzerine nitel bir araştırma (Doctoral dissertation). https://tez.yok.gov.tr/UlusalTezMerkezi/tezSorguSonucYeni.jsp

Leikin, R. (2009). Exploring mathematical creativity using multiple solution tasks. In Creativity in mathematics and the education of gifted students, ed. R. Leikin, A. Berman, and B. Koichu, 129_45. Rotterdam, the Netherlands: Sense Publishers.

Leikin, R. (2011). The education of mathematically gifted students: On some complexities and questions. Montana Mathematical Enthusiast Journal, 8(2), 167-188.

Leikin, R., Subotnik, R., Pitta-Pantazi, D., Singer, M., \& Peltzer, I. (2013). Teachers' views on creativity in mathematics education: An international survey. ZDM. The International Journal on Mathematics Education, 45(2), 309-324. http://dx.doi.org/10.1007/s11858-012-0472-4

Lev-Zamir, H., \& Leikin, R. (2011). Creative mathematics teaching in the eye of the beholder: focusing on teachers' conceptions. Research in Mathematics Education, 13(1), 17-32. http://dx.doi.org/ 10.1080/14794802.2011.550715

Lev-Zamir, H., \& Leikin, R. (2013). Saying versus doing: teachers' conceptions of creativity in elementary mathematics teaching. ZDM, 45, 295-308. http://dx.doi.org/ 10.1007/s11858-012-0464-4

Longo, C. (2010). Fostering creativity or teaching to the test? Implications of state testing on the delivery of science instruction. The Clearing House, 83, 54-57. http://dx.doi.org/ 10.1080/00098650903505399

Mann, E. L. (2006). Creativity: The essence of mathematics. Journal for the Education of the Gifted, 30(2), 236-260.

Meissner, H. (2005). Creativity and Mathematics Education. Proceeding of The Third East Asia Regional Conference on Mathematics Education. Shanghai, Nanjing, Hangzhou.

Meissner, H., (2008). Intuitive-Creative-Gifted-Logical. An Analysis for the Discussion Group 9 at ICME 11. Proceedings of the Discussing Group 9: Promoting Creativity for All Students in Mathematics Education, The 11th International Congress on Mathematical Education. Monterrey, Mexico. http://dg.icme11.org/tsg/show/10_

Miles, M. B., \& Huberman, A. M. (1994). An expanded source book: Qualitative data analysis. (2nd ed.) London: SAGE Publications.

Newton, D. P., \& Newton, L. D. (2009). Some student and teachers' conceptions of creativity in school science. Research in Science \& Technological Education, 27, 45-60. http://dx.doi.org/10.1080/02635140802658842

Özden, Y. (2005). Öğrenme ve ögretme (7. Bask1). Ankara: Pegem Yayıncılık. 
Pehkonen, E. (1997). The state-of-art in mathematical creativity. International Journal on Mathematical Education, 29(3), 63-67. http://dx.doi.org/ 10.1007/s11858-997-0001-z

Plucker, J. A., Beghetto, R. A., \& Dow, G. T. (2004). Why isn't creativity more important to educational psychologists? Potential, pitfalls, and future directions in creativity research. Educational Psychologist, 39, 83-96. http://dx.doi.org/10.1207/s15326985ep3902_1

Renzulli, J. S., Gentry, M., \& Reis, S. M. (2007). Enrichment clusters for developing creativity and high-end learning. Gifted and Talented International, 22, 39-47.

Rubenstein, L. D., McCoach, D. B., \& Siegle, D. (2013). Teaching for creativity scales: an instrument to examine teachers' perceptions of factors that allow for the teaching of creativity. Creativity Research Journal, 25(3), 324-334. http://dx.doi.org/ 10.1080/10400419.2013.813807

Runco, M. A. (2007). Creativity. Theories and themes: Research, development and practice. Burlington MA: Elsevier Academic Press.

Sheffield, L. J. (2005). Using creativity techniques to add depth and complexity to the mathematics curricula. Proceeding of The Third East Asia Regional Conference on Mathematics Education. Shanghai, Nanjing, Hangzhou.

Sheffield, L. J. (2008). Promoting Creativity For All Students in Mathematics Education: An Overview. Proceedings of the Discussing Group 9: Promoting Creativity for All Students in Mathematics Education, The 11th International Congress on Mathematical Education. Monterrey, Mexico.

Shriki, A. (2005). What do teachers know about creativity? Unpublished paper, Kesher-Ham - Israel National Center of Mathematics, Technion (In Hebrew).

Shriki, A. (2008). Towards promoting creativity in mathematics of pre-service teachers: The case of creating a definition. In R. Leikin (Ed.), Proceedings of the 5th International Conference on Creativity in Mathematics and the Education of Gifted Students (pp. 201-210). Haifa.

Shriki, A. (2010). Working like real mathematicians: developing prospective teachers' awareness of mathematical creativity through generating new concepts. Educational Studies in Mathematics, 73, 159-179. http://dx.doi.org/ 10.1007/s10649-009-9212-2

Sriraman, B. (2004). The characteristics of mathematical creativity. The Mathematics Educator, 14(1), 19-34.

Sriraman, B. (2005). Are giftedness and creativity synonyms in mathematics? The Journal of Secondary Gifted Education, 17, 20-36. http://dx.doi.org/ 10.4219/jsge-2005-389

Sternberg, R. J., \& Lubart, T. I. (2000). The concept of creativity: Prospects and paradigms. In R. J. Sternberg (Ed.), Handbook of creativity (pp. 93-115). New York: Cambridge University Press.

Treffinger, D. J., Young, G. C., Selby, E. C., \& Shepardson, C. A. (2002). Assessing creativity. Storrs, CT: The National Research Center on the Gifted and Talented.

\section{$(\mathrm{cc}) \mathrm{EY}$}

This work is licensed under a Creative Commons Attribution 3.0 License. 